\title{
DESIGN OF TARGET SYSTEMS FOR PRODUCTION OF PET NUCLIDES *
}

\author{
R.D. HICHWA, J.J. MOSKWA and E.A. HUGEL \\ Division of Nuclear Medicine, University of Michigan, Ann Arbor, Michigan 48109-0552, USA
}

\begin{abstract}
Target designs are presented for production of ${ }^{11} \mathrm{C},{ }^{13} \mathrm{~N},{ }^{15} \mathrm{O}$ and ${ }^{18} \mathrm{~F}$ by proton and deuteron reactions. Seven targets of two basic configurations (gas and water) and their respective manifold and control systems are detailed with design specifications and operational characteristics for the production of ${ }^{11} \mathrm{C}_{-} \mathrm{CO}_{2},{ }^{11} \mathrm{C}-\mathrm{HCN},{ }^{13} \mathrm{~N}-\mathrm{NH}_{4}^{+},{ }^{15} \mathrm{O}-\mathrm{O}_{2},{ }^{18} \mathrm{~F}-\mathrm{F}^{-}$and ${ }^{18} \mathrm{~F}-\mathrm{F}_{2}$ precursors. Short irradiation times $(5-20 \mathrm{~min})$ and high current $(30 \mu \mathrm{A})$ are used to produce near theoretical quantities of labeled PET precursors.
\end{abstract}

\section{Introduction}

Positron emission tomography is a diagnostic imaging technique that is used to noninvasively measure physiological and biochemical function of the human body. Short-lived positron emitting nuclides produced by compact cyclotrons are incorporated into specific biochemicals identical to or compatible with naturally occurring biomolecules within the body. The need to supply radionuclidic precursors on demand for clinical studies, radiopharmaceutical research and animal biodistribution studies taxes the production capabilities of many existing accelerator/target systems.

Early production of medically important positron emitters employed nuclear physics cyclotrons with limited beam output. Present compact cyclotrons (negative and positive ion) are designed to deliver up to 100 $\mu \mathrm{A}$ or more of current with a beam diameter of $\leq 10$ $\mathrm{mm}$. Cross sectional intensity of the beam is more uniform and approaches a step function in shape. Particles are extracted at fixed energies. Optimization of the cyclotron design contributes to its simplicity and, therefore, to its higher performance (higher extracted current).

Greater production yields are achieved by further optimizing the targetry for maximum utilization of cross-section and minimal loss of activity from incident particle scatter. Contamination of target materials (gases, tubes, target body, valves, etc.) can lead to competitive labeling of specific chemical sites with nonradioactive isotopes $\left({ }^{12} \mathrm{C}\right.$ for ${ }^{11} \mathrm{C}$ ) which reduces overall specific activity and diminishes the effectiveness of the particular radiopharmaceutical.

Target design criteria include: 1) simple, uncomplicated scheme; 2) a minimum number of joints and seals; 3) no welded joints or flanges; 4) a single thick

* Work supported in part by NINCDS Grant \# P01 NS15655. target foil to be used as a degrader and window made from the same material as the target body; 5) all window and target seals to be metal-to-metal, i.e. C-rings or crush metal joints; 6) standard target mounting hardware to permit interchangeability between locations on a multiple position target gantry or ladder; 7) quick disconnect fittings for casy, rapid attachment of cooling lines (air and water), 8) standard valves and fittings for easy replacement, 9) optimized target length, pressure and diameter for highest yield with lowest target volume; 10) sufficient target body mass to minimize temperature excursions during irradiation, and 11) computer as well as manual remote control of target sequencing, manifold operation and pressure and current readouts.

\section{2. ${ }^{11} \mathrm{C}$ targets}

The primary mechanisms for producing ${ }^{11} \mathrm{C}\left(t_{1 / 2}=\right.$ $20.38 \mathrm{~min})$ is from the ${ }^{14} \mathrm{~N}(\mathrm{p}, \alpha)^{11} \mathrm{C}$ reaction with a threshold energy of $4.5 \mathrm{MeV}$. Nuclidic contamination occurs from the competing reactions of ${ }^{14} \mathrm{~N}(\mathrm{p}, \mathrm{pn})^{13} \mathrm{~N}$ and ${ }^{14} \mathrm{~N}(\mathrm{p}, \mathrm{n}){ }^{14} \mathrm{O}$ with half-lives of ${ }^{13} \mathrm{~N}$ and ${ }^{14} \mathrm{O}$ being $9.96 \mathrm{~min}$ and $70.6 \mathrm{~s}$ respectively. Nearly all radiochemical syntheses of carbon compounds eliminate these radionuclidic impurities.

High and low pressure target designs are common $[1,2]$. The one shown in fig. 1 represents a high pressure, cylindrical target with a single window/degrader that drops the incident energy to $17.2 \mathrm{MeV}$ from $26 \mathrm{MeV}$. Table 1 provides design details. The length of the target exceeds the proton range by $110 \%$ to account for density reduction or rarification of the target gas by localized heat transfer to nitrogen molecules. Scatter from the foil/degrader is the primary cause of beam divergence. Scatter from the target gas at these pressures contributes only a few percent to beam widening. Dry, particulate free, air cooling rather than helium cooling is used to greatly simplify overall target operations. The 
Table 1

Target design specifications

\begin{tabular}{llcllllll}
\hline $\begin{array}{l}\text { Target } \\
\text { system }\end{array}$ & Shape & $\begin{array}{l}\text { Length } \\
(\mathrm{cm})\end{array}$ & $\begin{array}{l}\text { Diameter } \\
(\mathrm{cm})\end{array}$ & $\begin{array}{l}\text { Volume } \\
\left(\mathrm{cm}^{3}\right)\end{array}$ & $\begin{array}{l}\text { Target } \\
\text { body } \\
\text { material }\end{array}$ & $\begin{array}{l}\text { Entrance } \\
\text { window } \\
\text { material }\end{array}$ & $\begin{array}{l}\text { Window } \\
\text { thickness } \\
(\mathrm{mm})\end{array}$ & $\begin{array}{l}\text { Window } \\
\text { seal }\end{array}$ \\
\hline${ }^{11} \mathrm{C}$ & cylindrical & 30.5 & 2.9 & 201 & $\mathrm{Al}(6061)$ & $\mathrm{Al}(2024)$ & 1.59 & $\mathrm{Al} \mathrm{C-ring}$ \\
${ }^{13} \mathrm{~N}$ & $\sim$ hemispherical & 1.3 & 1.9 & 2.7 & $\mathrm{Al}(6061)$ & $\mathrm{Al}(2024)$ & 1.59 & crushed Al foil \\
${ }^{15} \mathrm{O}\left({ }^{15} \mathrm{~N}\right)$ & cylindrical & 15.2 & 2.2 & 58 & $\mathrm{Al}(2024)$ & $\mathrm{Al}(2024)$ & 2.29 & $\mathrm{Al} \mathrm{C-ring}$ \\
${ }^{15} \mathrm{O}\left({ }^{14} \mathrm{~N}\right)$ & cylindrical & 15.2 & 2.9 & 100 & $\mathrm{Al}(6061)$ & $\mathrm{Al}(2024)$ & 0.51 & $\mathrm{Al} \mathrm{C-ring}$ \\
${ }^{18} \mathrm{~F}\left({ }^{18} \mathrm{O}\right)$ & $\sim$ hemispherical & 0.5 & 1.8 & 0.9 & $\mathrm{Ag}(99.999 \%)$ & $\mathrm{Ag}(99.999 \%)$ & 0.64 & crushed Ag foil \\
${ }^{18} \mathrm{~F}\left({ }^{20} \mathrm{Ne}\right)$ & cylindrical & 14.9 & 3.2 & 120 & $\mathrm{Ni}(200)$ & $\mathrm{Ni}(200)$ & 0.13 & $\mathrm{NiC} \mathrm{C}$-ring \\
\hline
\end{tabular}

difference between the thermal conductivities of $\mathrm{He}$ and air is not as critical to the heat transfer as is the overall convective interface to remove the $244 \mathrm{~W}$ of dissipated energy within the degrader. Conical target shapes conform to the average Coulomb scattering angle but are more difficult to machine. A cylindrical target was chosen for its overall simplicity. The target manifold shown in fig. 2 is versatile. Standard valves $[3,4]$ are used for easy replacement. Stainless steel regulators and manifold tubes help to minimize stable carbon contamination.

High current $(30 \mu \mathrm{A})$ runs produce $>3 \mathrm{Ci}$ of activity within $20 \mathrm{~min}$. Two targets are employed for ${ }^{11} \mathrm{C}$ precursors, one target for ${ }^{11} \mathrm{C}-\mathrm{CO}_{2}$ and a second one for ${ }^{11} \mathrm{C}-\mathrm{HCN}$. Use of one target for both precursors leads to reduced specific activity of the ${ }^{11} \mathrm{C}-\mathrm{CO}_{2}$ molecule after runs with $5 \% \mathrm{H}_{2}$ target gas. Labeled ${ }^{11} \mathrm{C}$ carbon dioxide yields return to normal only after many target irradiations that alternate between zero grade $\mathrm{N}_{2}$ and $\mathrm{O}_{2}$ for the target gas.

Target sequencing operations include: 1) pressurization, 2) irradiation of a static system, and 3) release to the desired chemical processing location. A mass flow controller [5] is used to meter the target gas to the hot cell through small bore stainless steel tubes $(1.6 \mathrm{~mm}$ o.d.). Minimal gas dilution occurs with this process
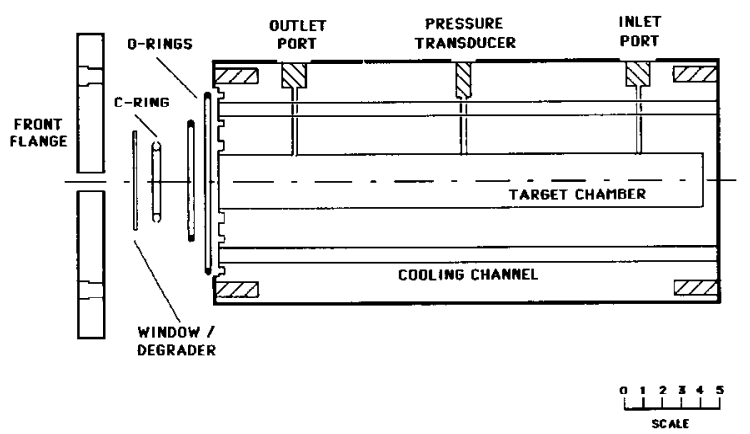

Fig. $1 .{ }^{11} \mathrm{C}$ target. Cylindrical, high pressure, high current target design that is representative of ${ }^{11} \mathrm{C},{ }^{15} \mathrm{O}\left({ }^{15} \mathrm{~N},{ }^{14} \mathrm{~N}\right)$ and ${ }^{18} \mathrm{~F}\left({ }^{20} \mathrm{Ne}\right)$ gas targets. Specific details for each system are given in table 1 .

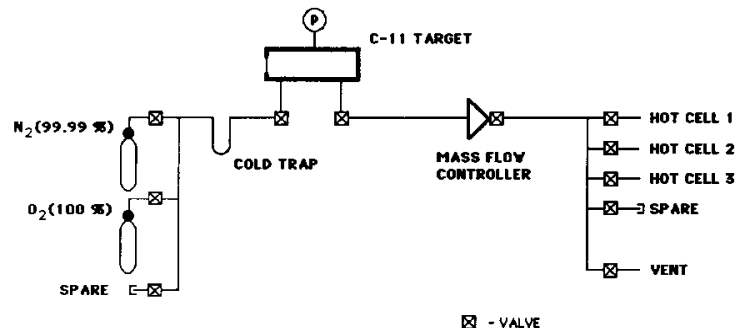

Fig. 2. ${ }^{11} \mathrm{C}$ manifold. A simple yet versatile manifold for pressurizing, venting, releasing and purging gas targets for production of ${ }^{11} \mathrm{C},{ }^{15} \mathrm{O}\left({ }^{14} \mathrm{~N}\right)$ an ${ }^{18} \mathrm{~F}\left({ }^{20} \mathrm{Ne}\right)$ is shown.

while permitting the user maximum control of gas delivery to the synthesis apparatus.

\section{3. ${ }^{13} \mathrm{~N}$ target}

Production of ${ }^{13} \mathrm{~N}$ is achieved through the ${ }^{16} \mathrm{O}(\mathrm{p}, \alpha){ }^{13} \mathrm{~N}$ reaction. ${ }^{15} \mathrm{O}\left(t_{1 / 2}=122 \mathrm{~s}\right)$ is also produced at energies above $17 \mathrm{MeV}$ by the ${ }^{16} \mathrm{O}(\mathrm{p}, \mathrm{pn}){ }^{15} \mathrm{O}$ reaction but does not contribute to problems with ${ }^{13} \mathrm{~N}$ radiochemistry. The target design is shown in fig. 3 and construction specifics are given in table 1 . The target operates statically with a $\mathrm{He}$ overpressure to $6.8 \mathrm{~atm}$ (100 psia). Optical sensors [6] clamped around the poly-

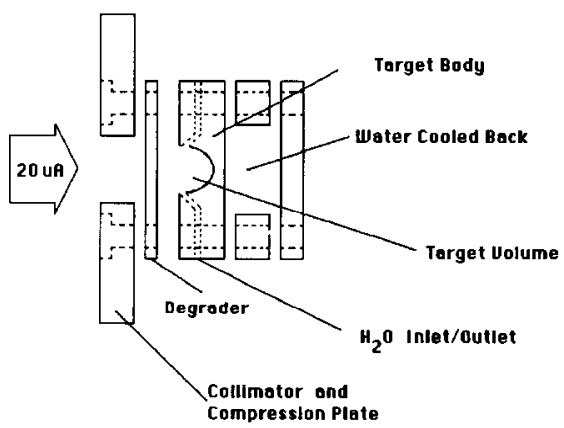

Fig. $3 .{ }^{13} \mathrm{~N}$ target. A simple high current, statically operated water target design suitable for ${ }^{13} \mathrm{~N}$ and ${ }^{18} \mathrm{~F}\left({ }^{18} \mathrm{O}\right)$ production. 
Table 2

Operational target characteristics ${ }^{\text {a) }}$

\begin{tabular}{|c|c|c|c|c|c|c|c|c|c|}
\hline Target & Reaction & $\begin{array}{l}\text { Target } \\
\text { material }\end{array}$ & $\begin{array}{l}\text { Degrader } \\
\Delta E \\
(\mathrm{MeV})\end{array}$ & $\begin{array}{l}\text { Incident } \\
\text { energy } \\
(\mathrm{MeV})\end{array}$ & $\begin{array}{l}\text { Current } \\
(\mu \mathrm{A})\end{array}$ & $\begin{array}{l}\text { Irradiation } \\
\text { time } \\
(\mathrm{min})\end{array}$ & $\begin{array}{l}\text { Initial } \\
\text { pressure } \\
\text { (atm) }\end{array}$ & $\begin{array}{l}\text { Beam on } \\
\text { pressure } \\
\text { (atm) }\end{array}$ & $\begin{array}{l}\text { Yield } \\
\text { (mCi EOB) }\end{array}$ \\
\hline$\overline{{ }^{11} \mathrm{C}}$ & ${ }^{14} \mathrm{~N}(\mathrm{p}, \alpha){ }^{11} \mathrm{C}$ & $\begin{array}{l}99.9 \% \mathrm{~N}_{2} \text { or } \\
5 \% \mathrm{H}_{2}: 95 \% \mathrm{~N}_{2}\end{array}$ & 8.1 & 17.2 & 30 & 20 & 20 & -40 & $>3100$ \\
\hline${ }^{13} \mathrm{~N}$ & ${ }^{16} \mathrm{O}(\mathrm{p}, \alpha){ }^{13} \mathrm{~N}$ & $\begin{array}{l}\text { deionized, } \\
\text { degassed } \mathrm{H}_{2} \mathrm{O}\end{array}$ & 8.1 & 17.2 & 20 & 5 & $6.8^{b)}$ & -10 & $>200$ \\
\hline \multirow[t]{2}{*}{${ }^{15} \mathrm{O}$} & ${ }^{15} \mathrm{~N}(\mathrm{p}, \mathrm{n}){ }^{15} \mathrm{O}$ & $99 \%{ }^{15} \mathrm{~N}_{2}$ & 12.7 & 12.7 & 30 & 6 & 17 & -33 & $>2800$ \\
\hline & ${ }^{14} \mathrm{~N}(\mathrm{~d}, \mathrm{n}){ }^{15} \mathrm{O}$ & $\begin{array}{c}1 \% \mathrm{O}_{2} \\
99 \%{ }^{14} \mathrm{~N}_{2} \\
1 \% \mathrm{O}_{2}\end{array}$ & 5.6 & 7.8 & 30 & 6 & 6.8 & -11 & $>1800$ \\
\hline \multirow[t]{2}{*}{${ }^{18} \mathrm{~F}$} & ${ }^{18} \mathrm{O}(\mathrm{p}, \mathrm{n}){ }^{18} \mathrm{~F}$ & $\begin{array}{r}95 \%{ }^{18} \mathrm{O}-\mathrm{H}_{2} \mathrm{O} \\
5 \%{ }^{16} \mathrm{O}-\mathrm{H}_{2} \mathrm{O}\end{array}$ & 9.0 & 16.4 & 20 & 25 & $6.8^{b)}$ & -10 & $>525$ \\
\hline & $\left.{ }^{2} \mathrm{Ne}(\mathrm{d}, \alpha)\right)^{18} \mathrm{~F}$ & $\begin{array}{l}99.9 \% \mathrm{Ne} \\
0.1 \%{ }^{19} \mathrm{~F}_{2}\end{array}$ & 5.4 & 8.1 & 15 & 50 & 10 & $\sim 15$ & $>190$ \\
\hline
\end{tabular}

a) Cyclotron energy for protons is $26 \mathrm{MeV}$ and for deuterons it is $15 \mathrm{MeV}$.

b) He overpressure.

ethylene tubing detect the presence of water and govern the control sequence. The hemispherical volume provides only two surfaces to be wetted by the target water. Visual observations of the filling/emptying procedure demonstrate that less than $2 \%$ residual water is held up in a target of this shape. A motorized rotary valve [7] permits filling, bombardment, and emptying to appropriate synthesis location with minimal dead volume. An absolute shutoff slider valve [8] is used to isolate the target from the manifold during irradiation and operation of the rotary valve. The target is vented immediately after bombardment. All wetted parts of the manifold are polyethylene or Teflon.

\section{4. ${ }^{15} \mathrm{O}$ targets}

Two reactions are employed to produce ${ }^{15} \mathrm{O}$ namely ${ }^{15} \mathrm{~N}(\mathrm{p}, \mathrm{n}){ }^{15} \mathrm{O}$ and ${ }^{14} \mathrm{~N}(\mathrm{~d}, \mathrm{n}){ }^{15} \mathrm{O}$. Higher energies than those used in table 2 will produce nuclidic contaminants of ${ }^{11} \mathrm{C}$ and ${ }^{13} \mathrm{~N}$. Appropriate scrubbers are used to

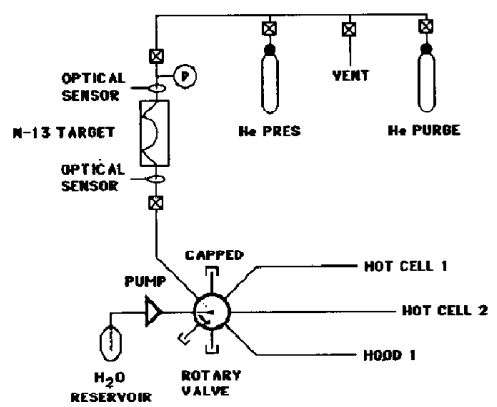

Fig. 4. ${ }^{14} \mathrm{~N}$ manifold. A representative manifold design for filling and releasing water targets for ${ }^{13} \mathrm{~N}$ and ${ }^{18} \mathrm{~F}\left({ }^{18} \mathrm{O}\right)$ nuclides. insure removal of any residual impurities. The incident energy is kept below the appropriate threshold of the competing nuclidic cross sections. Design for both target systems are very similar to the ${ }^{11} \mathrm{C}$ system as given in table 1. Fig. 5 shows the differences employed for the ${ }^{15} \mathrm{O}\left({ }^{15} \mathrm{~N}\right)$ target manifold. The ${ }^{15} \mathrm{O}\left({ }^{14} \mathrm{~N}\right)$ manifold is almost identical to the ${ }^{11} \mathrm{C}$ manifold shown in fig. 2 with the exception that the $\mathrm{CO}$ furnace and bypass are included on the output side of the manifold.

Operation of the ${ }^{15} \mathrm{O}\left({ }^{15} \mathrm{~N}\right)$ target is as follows: 1) pressurization through a small bore restrictor to $17 \mathrm{~atm}$ (250 psia); 2) irradiation of a static target; 3) tightly controlled release of $<10 \%$ (48 cc STP) target gas into the manifold through another restrictor by cycling the output solenoid valve; and 4) delivery of either ${ }^{15} \mathrm{O}-\mathrm{O}_{2}$ or ${ }^{15} \mathrm{O}-\mathrm{CO}$ to the desired location by following the target gas with a push gas $\left({ }^{14} \mathrm{~N}_{2}\right)$. Transport to the clinical PET scanners is by high speed bolus flow rather than steady state delivery. Recovery approaches $50-75 \%$ of EOB activity.

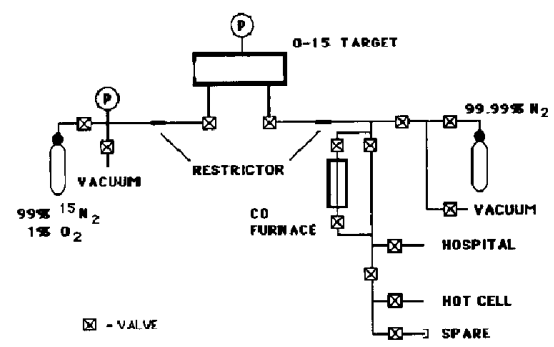

Fig. $5 .{ }^{15} \mathrm{O}\left({ }^{15} \mathrm{~N}\right)$ manifold. A low volume manifold designed for pressurizing a statically operated gas target. A fraction $(7.1 \%)$ of the target gas is released into the manifold and pushed as a bolus $(\sim 200 \mathrm{mCi})$ to the PET camera by stable ${ }^{14} \mathrm{~N}_{2}$ gas. 
Operation of the ${ }^{15} \mathrm{O}\left({ }^{14} \mathrm{~N}\right)$ target is identical to the standard ${ }^{11} \mathrm{C}$ system.

\section{5. ${ }^{18}$ F targets}

Two reactions are used for production of ${ }^{18} \mathrm{~F}\left(t_{1 / 2}=\right.$ $109.8 \mathrm{~min}):{ }^{18} \mathrm{O}(\mathrm{p}, \mathrm{n}){ }^{18} \mathrm{~F}$ and ${ }^{20} \mathrm{Ne}(\mathrm{d}, \alpha)^{18} \mathrm{~F}$. No competing reactions exist at the operational energies employed. Two systems are required for ${ }^{18} \mathrm{~F}$ production based on electrophilic $\left(F_{2}\right.$ from the ${ }^{20} \mathrm{Ne}(d, \alpha)$ reaction) and nucleophilic ( $F^{-}$from the ${ }^{18} \mathrm{O}(\mathrm{p}, \mathrm{n})$ reaction) syntheses.

The target/manifold system for the ${ }^{18} \mathrm{~F}\left({ }^{18} \mathrm{O}\right)$ target is similar to the ${ }^{13} \mathrm{~N}$ target. Silver is used instead of $\mathrm{Al}$ for the target body and window $[9,10]$. This reduces fluoride-metal complexes. The target volume is reduced by $200 \%$ from the ${ }^{13} \mathrm{~N}$ volume to minimize use of enriched ${ }^{18} \mathrm{O}$ water. Operation of the target is identical to the ${ }^{13} \mathrm{~N}$ target. A solenoid metering pump [11] delivers enriched water to the target. If failure of this pump occurs only one load of water will be lost which holds costs of a catastrophic ${ }^{18} \mathrm{O}-\mathrm{H}_{2} \mathrm{O}$ loss to a minimum.

The ${ }^{18} \mathrm{~F}\left({ }^{20} \mathrm{Ne}\right)$ target is similar to the ${ }^{11} \mathrm{C}$ design. The target body and window are constructed from nickel. The target is filled to the correct pressure $(0.3-2.0$ atm) with a $1 \%{ }^{18} \mathrm{~F}_{2}+99 \%$ Ne mixture and then topped off with pure $\mathrm{Ne}$ to $10.2 \mathrm{~atm}$. The target is irradiated statically and ported through a mass flow controller and small bore nickel tubing to the appropriate radiosynthesis site.

\section{Results}

Table 2 shows the operational characteristics for seven individual targets routinely used for labeled PET precursor production. Note the reaction and target configuration for the two ${ }^{11} \mathrm{C}$ targets are identical and therefore only one entry appears in table 2. The $\mathrm{H}_{2}$ admixture distinguishes ${ }^{11} \mathrm{C}-\mathrm{CO}_{2}$ from ${ }^{11} \mathrm{C}-\mathrm{HCN}$ production. At least $15 \mu \mathrm{A}$ and more commonly $30 \mu \mathrm{A}$ are used to irradiate each target. With the exception of the ${ }^{20} \mathrm{Ne}(\mathrm{d}, \alpha)$ reaction, short bombardment times (5-25 min) are employed.

\section{Conclusions}

Target systems for PET nuclide production should be simple, reliable and easy to maintain. Standard fittings, flanges, valves and seals contribute to these design criteria. Only two distinctly different target designs are necessary. For most major PET research facilities with proton and deuteron capability at least seven individualized targets are necessary. One target should be used for only one reaction or precursor type. Multiuse systems are possible but contaminants reduce specific activity. Clean fittings, and use of all metal seals and C-rings [12] further help to reduce contamination while maintaining high specific activity. Costs for enriched isotopes $\left({ }^{15} \mathrm{~N}_{2}\right)$ govern ${ }^{15} \mathrm{O}$ production between the proton and deuteron reaction. Lastly, to maintain a viable multipurpose PET center, short, high current target irradiations hetter utilize overall facility resources and will lead to higher center productivity.

\section{References}

[1] J.C. Clark and P.D. Buckingham, Short-lived Radioactive Gases for Clinical Use (Butterworth, London, 1975).

[2] F. Helus and T.J. Ruth (eds.), Proc. First Workshop on Targetry and Target Chemistry, Heidelberg, 1985.

[3] Skinner Valve Division, Honeywell Inc., 95 Edgewood Ave., New Britain, CT 06051, USA.

[4] Spangler Vaive Co., S05 South Vermont Ave., Glendora, CA 91740, USA.

[5] Aalborg Instruments \& Controls, Inc., 2 Melnick Dr., Monsey, NY 10952, USA.

[6] Pulnix America, Inc. 770 Lucerne Dr., Sunnyvale, CA 94086, USA

[7] Hamilton, Co., P.O. Box 10030, Reno, NV 89520, USA.

[8] Altech Associates, Inc., 2051 Waukegan Rd., Deerfield, IL 60015 , USA

[9] T.J. Tewson, M.S. Berridge, L. Bolumey and K.L. Gould, Nucl. Med. Bio. 15 (1988) 499.

[10] G.K. Mulholland, R.D. Hichwa, M.R. Kilbourn and J.J. Moskwa, Proc. 7th Int. Symp. on Radiopharm. Chem., 1988.

[11] Valcor Scientific, 2 Lawrence Rd., Springfield, NJ 07081, USA.

[12] Helicoflex Company, 400 Myrtle Ave., Boonton, NJ 07005 , USA. 